\title{
Isolation of Spiroplasma citri from Flowers and Seeds Collected from Infected Periwinkles
}

\author{
C. J. Chang and Bixing Zheng, Department of Plant Pathology, College of Agricultural and Environmental \\ Sciences, University of Georgia, Griffin 30223
}

\begin{abstract}
Chang, C. J., and Zheng, B. 1999. Isolation of Spiroplasma citri from flowers and seeds collected from infected periwinkles. Plant Dis. 83:60-61.

Isolations were attempted from flowers, stems, and seeds from six Spiroplasma citri-infected periwinkles and from flowers and stems from two healthy plants. Each flower was separated into four parts: petals, sepals, pistils, and corolla tubes. A total of 140 seeds from infected plants were germinated, with a germination rate of 59\%. Two and three months after germination, 25 plants from seeds were sampled for the isolation of $S$. citri. The average spiroplasma cells g-1 of diseased pistils, sepals, petals, corolla tubes, or stems was $1.87 \times 10^{8}, 1.9 \times 10^{7}, 1.89 \times 10^{6}, 3.7$ $\times 10^{6}$, or $2.35 \times 10^{6}$, respectively. The number of cells isolated from pistils was significantly higher than that from stems, whereas the numbers from sepals, corolla tubes, and petals were comparable to those from stems. No spiroplasma was isolated from flower parts of two healthy plants, from seeds, or from samples collected from 25 plants grown from seeds. Results indicated that flowers were good sources for the isolation of S. citri and confirmed that there is no seed transmission of the $S$. citri infection in periwinkles.
\end{abstract}

The diseased tissues commonly used for the isolation of spiroplasmas are young stems, leaves, petioles, or roots, even though citrus seeds had been mentioned (1,5). Bove et al. (1) mentioned that aborted seeds associated with the stubborn disease are a good source for isolation of Spiroplasma citri. Flowers are rarely used as the source for the isolation of phytopathogenic spiroplasmas, even though flowers were widely used for the isolation of certain epiphytic microorganisms, including some flower spiroplasmas and acholeplasmas $(4,8)$. Due to the fact that $S$. citriinfected periwinkles continue to produce smaller flowers until severely wilted (3), and no reports exist describing the use of infected flowers as the source of $S$. citri isolation, we conducted a project to investigate the possibility of isolating $S$. citri from infected flowers, seeds, and seedlings germinated from the seeds collected from infected plants. For as long as the phytoplasmas remain uncultivable (7), a search for proper medium ingredients and source of tissues for primary isolation is essential to this difficult task. Results of this project may provide important information for the eventual cultivation of phytoplasmas.

Corresponding author: C. J. Chang

E-mail address:cchang@gaes.griffin.peachnet.edu

Accepted for publication 5 October 1998.

Publication no. D-1998-1106-03R

(C) 1999 The American Phytopathological Society

\section{MATERIALS AND METHODS}

Isolation of $S$. citri from flowers and stems. Six $S$. citri-infected periwinkles and two healthy plants of the same age were used as the source of test flowers and stems. All six periwinkles were infected by graft-transmission, using one $S$. citri-infected scion per each healthy periwinkle, on 22 August 1996. Samples were collected from these eight plants on 26 May 1997 and used for isolation in $R_{2}$ medium (2). A total of 10 flowers and 2 stems were randomly picked from each plant. Each flower was carefully separated into four parts: petals, sepals, pistils, and corolla tubes. Tender stems of each plant were used for comparison. The amounts of pistils and sepals used for isolation from each plant were either $0.001 \mathrm{~g}$ or $0.01 \mathrm{~g}$, whereas those of petals, corolla tubes, and stems were $0.1 \mathrm{~g}$. The isolation was conducted by using a razor blade to mince the individual parts finely in $1 \mathrm{ml}$ of $\mathrm{R}_{2}$ medium, followed by a Millipore $(0.45 \mu \mathrm{m})$ filtration. A 10-fold serial dilution, starting with adding $0.1 \mathrm{ml}$ of the filtrate into 0.9 $\mathrm{ml}$ of fresh $\mathrm{R}_{2}$ medium, was performed through $1 \times 10^{-7}$. The culture tubes were incubated at $30^{\circ} \mathrm{C}$. The color-changing units signifying growth of $S$. citri were recorded for 20 to 22 days after initial isolation. The last culture tube in the dilution serial that had changed color was used to calculate the color-changing units per 1 $\mathrm{ml}$ of the final filtrate, which were then converted to the total cells per gram of respective tissues. The dark-field microscopic observation of the presence of $S$. citri cells was carried out for each tube in which the medium had changed color from red to yellow. Analysis of variance was applied to the spiroplasma cells isolated from various tissues with the GLM procedure (SAS Institute, Cary, NC). The least significant difference test was applied when the analysis of variance showed statistical significance $(P<0.05)$.

Isolation of $S$. citri from seeds and seedlings germinated from the collected seeds. Seeds collected from the six diseased plants were pooled together for isolations and germinations. Isolation of $S$. citri was done by grinding 20 seeds (approximately $0.02 \mathrm{~g}$ ) in $1 \mathrm{ml}$ of $\mathrm{R}_{2}$ medium (two sets) or grinding 30 seeds (approximately $0.04 \mathrm{~g}$ ) in $2 \mathrm{ml}$ of $\mathrm{R}_{2}$ medium (two sets) followed by a Millipore filtration $(0.45 \mu \mathrm{m})$ of the suspension. The filtrate $(1 / 10 \mathrm{ml})$ was pipetted into $2.5 \mathrm{ml}$ of fresh $\mathrm{R}_{2}$ medium, which was incubated at $30^{\circ} \mathrm{C}$ for up to 30 days before a conclusion was drawn. Of the collected seeds, a total of 140 seeds were germinated and the rate of germination was recorded. Each seedling was transferred into a 5-in. pot 1 month after germination for symptom development, if any. In all, 25 plants were sampled for the isolation of $S$. citri 1 and 2 months after they were transferred into individual pots following the method mentioned above, except that the ratio between plant tissues and $R_{2}$ medium was set at $1: 3$ (g:ml).

\section{RESULTS AND DISCUSSION}

Isolation of $S$. citri from flowers and stems. None of the 70 culture tubes used for the isolation of $S$. citri from two healthy periwinkles changed color from red to yellow, indicating that no spiroplasma cells were found in all four parts of flowers and stems. Of the 210 culture tubes that were used for the isolation of $S$. citri from six diseased plants, some started to change culture medium color from red to yellow as early as 6 days and some as late as 18 days after initial isolation. The final color-changing units were recorded 22 days after initial isolation. The average number of spiroplasma cells per gram of tissue (Table 1) for each plant was calculated based on the color-changing units and the amount of tissues used in the isolation. The average number of spiroplasma cells per gram of pistils was significantly higher than per gram of stems, whereas the numbers for corolla tubes, sepals, and petals were comparable to the number for stems. These results seemed to indicate that the 
flowers were good sources for the isolation of S. citri.

Liao et al. (6) reported that both corn and periwinkle stem extracts suppressed the growth of $S$. citri. For corn stem extracts, the inhibitory action was detected at a dilution of up to $1 / 160$ (corn stem extract/C-3G medium), whereas the action was detected at a dilution of 1/40 for periwinkle extracts. A study was carried out to compare the inhibitory action of the periwinkle stem extracts and flower extracts. The same amount of stem or whole-flower tissues collected from diseased periwinkles was minced in fresh $R_{2}$ medium at a ratio of 1:3 (g:ml). The sap was filtered through $0.45-\mu \mathrm{m}$ Millipore filters. The filtrates, labeled stem extracts or flower extracts, were used as the inocula for S. citri. A 10fold serial dilution, starting by adding 0.1 $\mathrm{ml}$ of each filtrate to $0.9 \mathrm{ml}$ of fresh $\mathrm{R}_{2}$ medium for up to $1 \times 10^{-6}$, as performed at $0,12,24,48,72$, and $96 \mathrm{~h}$ after the initial filtration. A total of three stem tissues and three flower tissues from three different periwinkles were evaluated. S. citri survived in stem extracts for up to $48 \mathrm{~h}$ and in flower extracts for up to $96 \mathrm{~h}$. The average cells $/ \mathrm{ml}$ in the stem filtrates after $48 \mathrm{~h}$ were $10^{3}$-fold fewer than the number found in the filtrate at $0 \mathrm{~h}$ after filtration. The average cells $/ \mathrm{ml}$ in the flower filtrates after $96 \mathrm{~h}$ remained about the same as the number found in the filtrate at $0 \mathrm{~h}$ after filtration. (C. J. Chang, unpublished). Data seemed to suggest that flower extracts were not as inhibitory to the growth of $S$. citri as stem extracts. Virescent flowers may be worth trying for the isolation of phytoplasmas.

Table 1. Numbers of Spiroplasma citri cells (cell $\log _{10} / \mathrm{gram}$ of tissue) in petals, sepals, pistils, corolla tubes, and stems of diseased periwinkles ${ }^{\mathrm{x}}$

\begin{tabular}{lccccccc}
\hline & \multicolumn{7}{c}{ Cell $\log _{\mathbf{1 0}}(\mathbf{C C U} / \mathbf{g}$ of tissue) } \\
\cline { 2 - 6 } Plant part & Plant 1 & Plant 2 & Plant 3 & Plant 4 & Plant 5 & Plant 6 & Mean $^{\mathbf{z}}$ \\
\hline Pistil & 9 & 7 & 7 & 8 & 6 & 6 & $7.17 \mathrm{a}$ \\
Sepal & 8 & 6 & 6 & 7 & 6 & 6 & $6.50 \mathrm{ab}$ \\
Corolla tube & 7 & 7 & 5 & 6 & 6 & 5 & $6.00 \mathrm{bc}$ \\
Stem & 6 & 5 & 7 & 6 & 6 & 6 & $6.00 \mathrm{bc}$ \\
Petal & 7 & 5 & 5 & 6 & 4 & 5 & $5.33 \mathrm{c}$ \\
\hline
\end{tabular}

${ }^{\mathrm{x}}$ No $S$. citri was isolated from petals, sepals, pistils, corolla tubes, or stems of two healthy plants.

y $\mathrm{CCU}=$ color-changing unit.

${ }^{\mathrm{z}}$ Means followed by the same letter within a row are not significantly different (least significant difference $P<0.05$ ) according to the GLM procedure in SAS (SAS Institute, Cary, NC).

Isolation of $S$. citri from seeds and seedlings germinated from collected seeds. Four different sets of isolations of $S$. citri from seeds collected from diseased periwinkles were negative. The germination rate of the seeds collected from diseased periwinkles was 59\% (82/140). Of the 25 seedlings used for the isolation of $S$. citri 2 to 3 months after germination, the isolation was negative. The fact that no symptom was observed in any of the seedlings 5 months after germination confirmed that there was no seed transmission of $S$. citri in periwinkles.

\section{LITERATURE CITED}

1. Bove, J. M., Whitcomb, R. F., and McCoy, R. E. 1983. Culture techniques for spiroplasmas from plants. Pages 225-234 in: Methods in Mycoplasmology, Vol. II. J. G. Tully and S. Razin, eds. Academic Press, New York.

2. Chen, T. A., Wells, J. M., and Liao, C. H. 1982. Cultivation in vitro: spiroplasmas, plant mycoplasmas, and other fastidious, walled prokaryotes. Pages 417-446 in: Phytopathogenic Prokaryotes, Vol. 2. M. S. Mount and G. H. Lacy, eds. Academic Press, New York.
3. Daniels, M. J. 1979. Mechanisms of spiroplasma pathogenicity. Pages 209-227 in: The Mycoplasmas, Vol. III. R. F. Whitcomb and J. G. Tully, eds. Academic Press, New York.

4. Davis, R. E. 1978. Spiroplasma associated with flowers of the tulip tree (Liriodendron tulipifera L.). Can. J. Microbiol. 24:954-959.

5. Kloepper, J. W., Garrott, D. G., and Oldfield, G. N. 1982. Quantification of plant pathogenic spiroplasmas from infected plants. Phytopathology 72:577-581.

6. Liao, C. H., Chang, C. J., and Chen, T. A. 1979. Spiroplasmostatic action of plant tissue extracts. Pages 99-103 in: Proc. R.O.C.-U.S. Coop. Sci. Semin. Mycoplasma Dis. Plants. Hong-Ji Su and R. E. McCoy, eds. National Science Council, Taipei, Taiwan.

7. McCoy, R. E., Caudwell, A., Chang, C. J., Chen, T. A., Chiykowski, L. N., Cousin, M. T., Dale, J. L., de Leeuw, G. T. N., Golino, D. A., Hackett, K. J., Kirkpatrick, B. C., Marwitz, R., Petzold, H., Sinha, R. C., Sugiura, M., Whitcomb, R. F., Yang, I. L., Zhu, B. M., and Seemuller, E. 1989. Plant diseases associated with mycoplasma-like organisms. Pages 546-640 in: The Mycoplasmas. Vol. V. R. F. Whitcomb and J. G. Tully, eds. Academic Press, New York.

8. McCoy, R. E., Williams, D. S., and Thomas, D. L. 1979. Isolation of mycoplasmas from flowers. Natl. Sci. Counc. (Taiwan) Symp. Ser. 1:75-81. 